\title{
Financial sector development and economic growth: evidence from Cameroon
}

\author{
Janice Tieguhong Puatwoe ${ }^{*}$ and Serge Mandiefe Piabuo
}

\author{
* Correspondence: \\ puatwoejanice@gmail.com \\ TTRECED-CAMEROON, \\ YaoundeCentreCameroon
}

\begin{abstract}
For decades, African economies have embarked on financial sector reforms. However, the empirical implications of these reforms have been divergent. This paper investigates the impact of financial development on Economic growth using time series data in Cameroon. This investigation was carried out using three common indicators of financial development (broad money, deposit/GDP and domestic credit to private sector). Using the Auto Regressive Distributive Lag (ARDL) technique of estimation, it was discovered that there exist a short-run positive relationship between monetary mass (M2), government expenditure and economic growth, a short run negative relationship between bank deposits, private investment and economic growth equally exists. However in the long run, all indicators of financial development show a positive and significant impact on economic growth. This paper thus confirms the existence of a positive and long-term impact of all the indicators of financial development on economic growth through bound test. It is therefore proposed that the financial reforms in Cameroon should be pushed forward in order to boost the development of the financial sector thus an increase in its role on economic growth.

Keywords: Financial development, Economic growth, Financial intermediation, Endogenous growth
\end{abstract}

\section{Background}

The accumulation of financial assets at a more rapid rate than the accumulation of nonfinancial assets is called financial development according to Shaw (1973). According to Levine (2004), financial development occurs when financial instruments, financial markets and financial intermediaries, reduce without necessarily eliminating the costs of obtaining information, the costs of executing contracts and the costs of transaction, as a consequence do a better job by offering financial functions. Economists' understanding of the nature and relationship which exist between financial systems and economic growth has evolved over time.

The role of the financial system on economic development has attracted and received increased attention from both academia and policy makers (Ndikumana 2001), with resulting divergent views emerging. Over the past decades, focus on this area has increased, with mixed findings which remains a theoretical and empirical controversy (Boulika and Trabelisi 2002). Financial development has played a leading role

(c) The Author(s). 2017 Open Access This article is distributed under the terms of the Creative Commons Attribution 4.0 International License (http://creativecommons.org/licenses/by/4.0/), which permits unrestricted use, distribution, and reproduction in any medium, provided you give appropriate credit to the original author(s) and the source, provide a link to the Creative Commons license, and indicate if changes were made. 
in many developing economies. There is a widespread believe among policy makers that financial development enhances productivity which promotes growth. The various findings made on financial development and economic growth varies due to different methods used in research. Some researchers found that financial development has a positive effect on economic growth (Kar and Pentecost 2000; Boulika and Trabelisi 2002) while others arrive at an opposite conclusion (Lucas 1988; Stern 1989).

Contemporary finance researchers have extensively investigated the link between financial liberalization and other macroeconomics variables, but the role of financial development is not universally accepted. One of the oldest findings on the relationship between financial development and economic growth is based on Schumpeter (1912) who asserts that, the services provided by the financial intermediaries are important for innovation and development. According to Bagehot (1873) and Hicks (1969), development in the financial system played a critical role in industrialising England through the facilitation of capital mobilisation. Schumpeter (1912) harnesses the importance of the banking system in economic growth; financial institutions support innovation and creativity and thus enhance future growth by identifying and funding productive investments. Therefore, it facilitates the creation of wealth, trade and the formation of capital (Ahmed 2006). A further step taken by Fry $(1978,1980)$ and Galbis (1977) suggested that, interventions to impose restrictions on the banking system such as credit ceilings and high reserve requirements have a negative impact on the development of the financial sector, which ultimately reduces economic growth. In addition, (Levine 1997) suggested that aiding risk management, improving liquidity and reducing transaction costs leads to financial system development and thus encourages investments.

However, Lucas (1988) and Stern (1989) suggested that there is no relationship between financial system development and economic growth. According to Lucas (1988) finance is an "overstressed" determinant of economic growth. Therefore, any strategies aimed at promoting financial system development would be a waste of resources, as it diverts attention from more relevant policies such as labour and productivity improvement programs, implementation of pro-investment tax reforms, encouragement of exports; amongst others.

Other researchers suggest that the financial system develops in response to improved economic growth. According to Robinson (1952) "where enterprise leads, finance follows", that is, as an economy grows the financial sector responds to the demands of the economy. A number of studies (Gurley and Shaw 1955; Goldsmith 1969; Jung 1986; Kar and Pentecost 2000; Boulika and Trabelisi 2002; Islam 2004; Güryay et al. 2007) suggest a unidirectional causality running from growth to finance. Countries whose economies grow faster, are forced to devote more investment on improving their financial system in order to stabilise their economic environment (Padilla and Mayer 2002).

On the other extreme are those who suggest that financial system development is anti-growth (Van Wijnberg 1983, Buffie 1984). Development in financial system facilitates risk amelioration and efficient resource allocation; this may reduce the rate of savings and risk, consequently leading to lower economic growth (Levine 2004). However, this follows the basic assertion that, where there is high risk there is high return.

From the empirical evidence above, it can be noticed that there is divergence in the effect of financial development on economic growth. These studies also show divergence in results of the direction of causality between financial development and 
economic growth in the short-run and in the long-run. These views vary due to changing dynamics of financial policies in the countries studied and the response of these economies to policies, level of development and governance equally vary substantially. All these divergent views give enough reasons to investigate the impact of financial development on economic growth in Cameroon. Previous studies carried out in Cameroon used co-integration regression model (Tabi et al. 2011), and panel regression model (Elie 2015). This paper distinguishes itself from the others in so many aspects; firstly it uses three indicators of financial development which permits the researchers to capture all aspects of bank based financial development. Secondly to the best of our knowledge, no paper has investigated the relationship between financial development and economic growth in Cameroon using the Auto Regressive Distributive Lag model (ADRL). This model permits the verification of short-run and long-run relationships, it equally allows the use of variables integrated at different levels and it produces robust results (Narayan 2005) and is appropriate when a sample size is small (Odhiambo, 2008). Previous studies in Cameroon did not capture recent economic and financial dynamics since the time frame of their studies date back to 2006. Thirdly, this paper will equally contribute to literature by incorporating recent time series data which captures recent policies aimed at liberation and regulation of the financial sector. In this direction, this paper seeks to respond to the following research question: Is there a shortrun or long-run relationship between financial development and economic growth?

\section{Financial system of Cameroon}

Cameroon harbors the Bank of Central African States (BEAC), which is the central bank of all the member states of the Economic Community of Central Africa States (CEMAC) to which Cameroon belongs with headquarters being in Yaoundé. Commercial banks, postal banks (CAMPOST), insurance companies, non-banking financial institutions, and the Douala Stock Exchange (established in 2002) are under the supervision of this central bank. This central bank (BEAC) replaced the central bank of the states of Equatorial Africa which Cameroon became a member in 1972. In 1993 the member states of BEAC created a supervisory authority, known as Commission Bancaire de l'Afrique central (COBAC) whose role is to secure and regulate the regions banking system. In 1999, Cameroon's banking system consisted of nine commercial banks with 60 branches. Although bank branches decreased from 105 in the year 1995 to 104 in the year 2005 and as well became concentrated in the big cities, there was however a significant increase in the number of banks from eight banks in 1995 to 10 in 2005. This number has increased further to 15 in 2017 with Credit Communautaire d'Afrique(CCA) gaining the status of a commercial bank. The banking sector plays a major role in the financial sector of Cameroon; it accounted for about $84.4 \%$ of the total assets of the financial sector in 2005, and contributed 19.6\% to GDP. Although the financial sector in Cameroon is still not well-developed, it encompasses the largest financial sector in the CEMAC zone, and contributes about 55\% of CEMAC's financial assets in 2005, the bulk of which is from the banking sector.

Nevertheless, a number of factors have contributed to the current underdevelopment of the Cameroonian financial sector. The financial system in Cameroon which is still in its infancy operates with very limited amount of financial instruments and constitutes 
mostly of banks as the main arm, with an underdeveloped financial market. The underdevelopment of the Cameroonian banking sector can be attributed to financial repression with the key elements being the extensive presence of the government within the financial sector and government ownership of major financial institutions. For instance, in 1986, the government was the shareholder in six out of eight commercial banks, and possessed a majority ownership in two of them (IMF, 2007). In addition, there has been no significant development in institutions such as leasing institutions, housing institutions, and hire-purchase companies amongst others, with the activities of commercial banks in the country being reduced to a traditional banking function, focused on short-term lending, accounting for about 87.3\% of all credit to the economy in 1995 (IMF, 2007). Also, the distribution of banks in the economy is heavily skewed towards urban centers thus making a significant part of the country denied access to banking facilities. Furthermore, the use of physical cash is as well still much rampant and some economic actors still having very little knowledge on other banking services and financial instruments that can facilitate their transactions.

\section{Literature review}

Empirical investigation of the relationship between financial development and economic growth is abundant globally. Empirical evidence over time has not been conclusive on this relationship with three prominent outcomes from these studies; positive, negative and no impact. The tables below shows a summary of studies in different countries or regions, their major findings and it equally indicates the methodology used. The objective is to have a global view of countries or regions with positive, negative and no impact (Tables 1 and 2).

Financial development has played a leading role in many economies of Less Developed Countries (LEDCs) and Africa especially. Although the relationship between financial development and economic growth has received widespread attention in the modern history of economics, the conclusions have been far from conclusive. The finance growth nexus debate can be traced to the work of Schumpeter (1911) during the early twentieth Century. The thrust of the debate has been whether financial development has any impact on economic growth, and if it has, whether the impact is positive or negative. However, there has been a widespread believe among policy makers that financial development enhances productivity and thus promotes growth. From the panel 1 perspective, Fry 1988; Beck et al.(2000), Beck et Levine (2004), King and Levine (1993), Jeanneney et al. (2006) amongst other studies have found evidence that development of the financial sector leads(positive impact) to economic growth. In addition, from panel 2 perspective, Tabi et al. (2011), Elie (2015), Djoumessi (2009) and Madiefe (2015) have reinforced the argument that financial development has a positive impact on economic growth in Cameroon and some sub-Saharan African countries such as South Africa.

Despite the overwhelming evidence that financial system development has a positive impact on economic growth in panel 1 and 2, alternative points of views still exist. There are a number of studies that provide evidence in support of the fact that financial development has a negative impact on economic growth. Al-malkawi et al. (2012), De Gregorio and Guidotti (1995), Bernard and Austin (2011) amongst others found a negative impact of financial development on economic growth in certain countries. A 
Table 1 Literature review excluding Cameroon

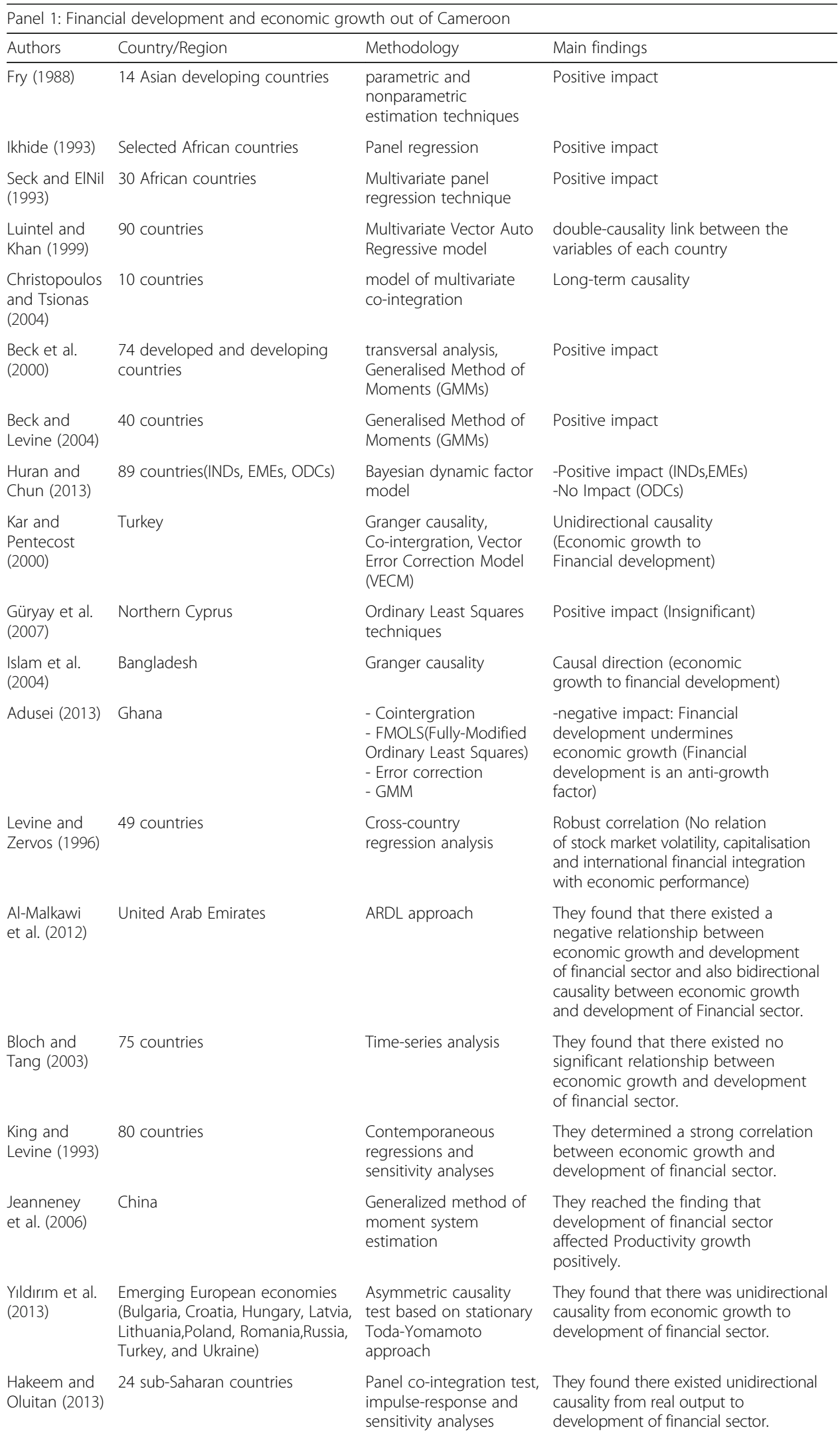


Table 1 Literature review excluding Cameroon (Continued)

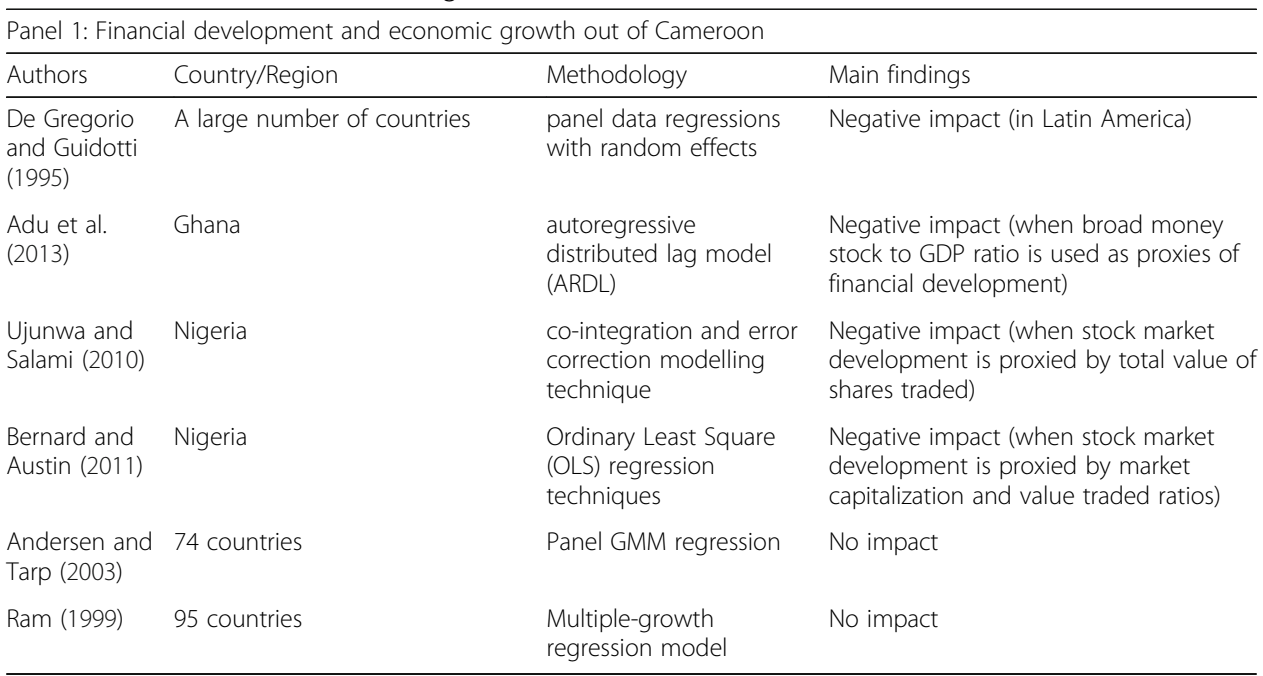

Source: Compiled by author

close view of the major results shows developing countries are more likely to report a negative impact of financial development on economic growth. This can be due to country specific characteristics, institutional framework and governance related issues.

In addition to the strong view that there is a relationship between financial development and economic growth, irrespective of whether this relationship is positive or negative, there have been a few studies that suggest that financial development has no impact on economic growth. These studies provide evidence in support of the notion that financial development and economic growth are not related and they are two different phenomena that are independent of one another. Such studies include Bloch and Tang (2003), Levine and Zervos (1996), Ram (1999), Andersen \& Trap (2003). Furthermore, some empirical studies such as Yıldırım et al. (2013), Hakeem and Oluitan (2013), Islam et al. (2004), Kar and Pentecost (2000) showed evidence that there exist a unidirectional causality from economic growth to financial development in some countries. On the other extreme, Adusei (2013) provides evidence that financial development undermines growth in an economy (financial development is an anti-growth factor).

\section{Data and methodology}

Data

The time series variables retained for this study covers the period 1980-2014(34 years).The variables (dependent and independent) are extracted from the World Development Indicators (WDI, 2016) of the World Bank.

Model

The empirical link between financial development and economic growth to be estimated in this paper is adapted from a simple model developed by De Gregorio and Guidotti (1995) and Abduroluman (2003). In this model the financial development variable is included in an endogenous growth model. The model shows how indicators of financial development through economic relations turn to have an impact on 
Table 2 Financial development and economic growth in Cameroon

\begin{tabular}{|c|c|c|c|}
\hline Author(s) & Country/Region & Methodology & Main findings \\
\hline Tabi et al. (2011) & Cameroon & $\begin{array}{l}\text { Johansen method of } \\
\text { co-integration analysis }\end{array}$ & Positive effect \\
\hline Elie (2015) & $\begin{array}{l}21 \text { Sub-Saharan } \\
\text { African (SSA) } \\
\text { countries }\end{array}$ & $\begin{array}{l}\text { dynamic panel GMM } \\
\text { technique }\end{array}$ & $\begin{array}{l}\text { positive link between financial development } \\
\text { and economic growth }\end{array}$ \\
\hline Djoumessi (2009) & $\begin{array}{l}\text { Cameroon and } \\
\text { South Africa }\end{array}$ & ARDL, VECM & $\begin{array}{l}\text {-positive impact (In Cameroon when the two } \\
\text { methods of estimation are used) } \\
\text {-Positive impact in South Africa when VECM is } \\
\text { used and independent relationship when ARDL } \\
\text { is used. }\end{array}$ \\
\hline Mandiefe (2015) & $\begin{array}{l}\text { Cameroon and } \\
\text { South Africa }\end{array}$ & VECM & $\begin{array}{l}\text {-(Positive) Long-run relationship between two } \\
\text { variables (Cameroon) } \\
\text {-Short-run relationship between bank deposits } \\
\text { and economic growth, long-run relationship } \\
\text { between economic growth financial development } \\
\text { and (South Africa) }\end{array}$ \\
\hline
\end{tabular}

Source: Compiled by author

economic growth. The equation below shows the functional and econometric relationship between the variables of the study.

Economic growth $=\mathrm{f}($ financial development, macro-economic environment $)$

Economic growth $(G D P)=\alpha+\beta_{1}$ domestic credit to private sector ${ }_{t}$

$$
\begin{aligned}
& +\beta_{2} \text { bank deposits }_{t}+\beta_{3} M 2_{t} \\
& +\beta_{4} \text { private investment }_{t} \\
& +\beta_{5} \text { government expendituret }_{t}+\varepsilon_{t}
\end{aligned}
$$

Where $\alpha=$ constant, $\varepsilon_{\mathrm{t}}=$ error term, while $\beta_{1}, \beta_{2}, \beta_{4}, \beta_{5}$, are coefficients.

\section{Independent variables}

Indicators of financial development

Financial development is captured through two aspects of the financial system of Cameroon; financial depth and financial efficiency.

Financial depth With inspiration from Financial Development and Structure Dataset (FDSD) and finance literature (Asongu 2011a, b, c, d), this paper measures financial depth from two perspectives; Broad money which captures broad money and demand while financial system deposits captures savings and time deposits, which are both expressed as a percentage of GDP. Economic and financial sector indicators will be used, broad money (M2/GDP) and financial system deposits (Deposits).

Financial efficiency The efficiency of a financial system is the ability of the system to perform its principal role of transforming deposits to credits (Asongu 2012). Domestic credit to private sector is used in this paper as an indicator of financial efficiency. 


\section{Control variables}

\section{Government expenditure}

This control variable captures the effect of government expenditure. The choice of variable is inspired by the fundamental role of public expenditure in spurring economic activities and development.

\section{Private investment}

This variable captures gross formation of fixed capital, and permits us to see how investment increases output which subsequently leads to economic growth.

\section{Dependent variable}

\section{GDP growth rate}

This variable captures the rate at which the economy grows from 1 year to another; it captures value added from year to year.

\section{Model and estimation procedures}

This research will make use of a technique suggested by Pesaran et al. (2001) known as Autoregressive Distributive Lag Model (ARDL), which is based on the general to specific modelling technique. In order words, this research utilises the newly proposed autoregressive distributive lag (ARDL) approach which was developed and introduced by Pesaran and Shin (1995 and 1998), Pesaran et al. (1996), Pesaran (1997) and Pesaran et al. (2001), and later revised by Nayaran (2005) for the case of small sample size data(30-80 observations).

The Autoregressive Distributive Lag (ARDL) model is adopted as a method of estimation in this study. This model is advantageous over other techniques of cointegration because it permits the use of variables that become stationary without differencing $(\mathrm{I}(0)$ and variables that become stationary after first differentiation $\mathrm{I}(1)$, it does not accept variables that become stationary after second differentiation (I(2)). Also, this technique can be applied irrespective of whether the variable is $\mathrm{I}(0), \mathrm{I}(1)$ or fractionally co-integrated (Pesaran 1997). Rather than having a multiple equation to estimate as in the case of the Vector Autoregressive (VAR) model, it involves just a single-equation set-up, which makes it simple to implement and interpret. Also different variables can be assigned different lag-lengths as the model is entered. The ADRL technique is free of residual correlation since variables stand as a single equation; it is easy to derive the error correction model from simple linear transformation by integrating short run adjustments with long run equilibrium without loss of information. In addition, this model as well takes sufficient number of lags to capture the data generating process in a dynamic framework of general-to-specific modeling framework. Furthermore, the error correction term (ECT) which integrates short-run adjustments with long-run equilibrium without losing long-run information, can be derived from ARDL through a simple linear transformation.

The long-run and causal relationship between financial development and economic growth in Cameroon using the Narayan (2005) test will be performed in several steps. First, the order of integration of variables will be verified using the test of unit roots through the Augmented Dickey Fuller test (ADF) and Phillip-Perron test. A great advantage of Philips-Perron (PP) test is that it is non-parametric; that is, it does not require the selection of the level of serial correlation as in the case of ADF. Due to the 
complicated and dynamic structure of financial time series data, ADF and Phillip Perrons tests are best suited for test of unit roots. It instead takes the same estimation scheme as in Dickey Fuller (DF) test, but corrects the statistic to conduct for autocorrelations and heteroscedasticity. The Augmented Dickey -Fuller (ADF) test is assumed superior due to its popularity and wide application. The ADF test adjusts the DF test to take care of possible autocorrelation in the error terms by adding the lagged difference term of the dependent variable. As for the PP test, it as well takes care of the autocorrelation in the error term and its asymptotic distribution is the same as that of the ADF test statistic. However, ADF is commonly used because of its easy applicability. Then, the number of lags will further be verified using the Akaike information criteria and Schwarz information criteria. Secondly, the model will be estimated using Ordinary Least Square (OLS) technique and test for long-run causality between financial development and economic growth using the Narayan test. The Narayan test is preferred to that constructed by Peseran et al. (2001) because this test is best adapted for small sample sizes (30 to 80 observations) while Peseran et al. (2001) is adapted for large sample sizes (500 to 1000 observations). The third step entails the estimation of the long-run variables, and then residuals are converted and inserted as an error correction term in the model. The model is estimated with the error correction term in order to capture its long-run speed of adjustment. Also, the Wald Test is used to verify the short-run effect of financial development on economic growth.

The presence of an error-correction term among a number of co-integrated variables shows that changes in the dependent variable is a function of both the level of disequilibrium in the co-integration relationship (represented by the ECM) and the changes in other explanatory variables. This therefore implies that any deviation from the long-run equilibrium will feed back into the changes in the dependent variable, thereby forcing the movement towards the long-run equilibrium (Masih, 2002). However, this research explores the issues surrounding co-integration analysis and the Error Correction model within the Distributed Lag model framework that is, the Autoregressive Distributed Lag Approach to co-integration.

Recall that the basic form of an ARDL model is:

$$
\mathrm{y}_{\mathrm{t}}=\beta_{0}+\beta_{1} \mathrm{y}_{\mathrm{t}-1}+\ldots \ldots .+\beta_{\mathrm{k}} \mathrm{y}_{\mathrm{t}-\mathrm{p}}+\alpha_{0} \mathrm{x}_{\mathrm{t}}+\alpha_{1} \mathrm{x}_{\mathrm{t}-1}+\alpha_{2} \mathrm{x}_{\mathrm{t}-2}+\ldots \ldots \ldots+\alpha_{\mathrm{q}} \mathrm{x}_{\mathrm{t}-\mathrm{q}}+\varepsilon_{\mathrm{t}}
$$

Where $\varepsilon_{\mathrm{t}}$ is the random disturbance term which is serially independent and assumed to be well behaved or constant.

An Autoregressive Distributive Lag model is considered as an ARDL ( $p$ q) model whose reduced form is presented as:

$$
Y_{t=} \mu+\sum_{i=0}^{p} \alpha_{i} \Delta Y_{t-i}+\sum_{i=0}^{q} \beta_{i} \Delta X_{t-i}+\epsilon_{t}
$$

Where, $Y_{t}$ is the dependent variable with its lags as independent variables. $X_{t}$ Is the lagged independent variables and $\epsilon_{t}$ being the white noise.

Generally, using the lag operator $\mathrm{L}$ applied to each component of a vector.

$L^{k} X_{t}=X_{t-k}$, it is easy to defined the lag polynomial $\mathrm{A}(\mathrm{L})$ and the polynomial vector $\mathrm{B}(\mathrm{L})$.

The ARDL (p, q) is 


$$
\begin{aligned}
& \mathrm{A}(\mathrm{L}) Y_{t}=\mu+\mathrm{B}\left(X_{t}\right)+\mu_{t} \\
& \mathrm{~A}(\mathrm{~L})=1-\alpha_{1} L-\alpha_{2} L^{2} \ldots \ldots-\alpha_{P} L^{p} \\
& \mathrm{~B}(\mathrm{~L})=1-B_{1} L-B_{2} L^{2} \ldots \ldots-B_{P} L^{P} \\
& A(L) Y_{t}=\mu+B_{1}(L) X_{i t}+B_{2}(L) X_{2 t}+\ldots B_{k}(L) X_{k t}+\mu_{t}
\end{aligned}
$$

A detail specification of the model with respect to the variables of this study is presented below.

$$
\begin{aligned}
& \Delta \text { economic growth } \text { g }_{t}=\alpha_{0}+\sum_{i=1}^{p} \alpha_{i} \text { seconomic growth } h_{t-i} \\
& +\sum_{i=0}^{q} \beta_{i} \Delta \text { financial development }_{t-i}
\end{aligned}
$$

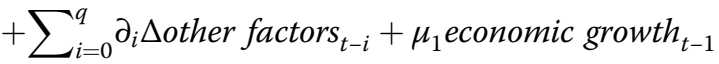

$$
\begin{aligned}
& +\mu_{2} \text { financialdevelopment }_{t-1}+\mu_{1} \text { other factors } \text { fi-1 }_{t}+\varepsilon_{t}
\end{aligned}
$$

Where $\Delta$ refers to the first difference operator and $\varepsilon_{t}$ being the error term.

After the estimation of the above model, the long-run causality test is carried out by comparing the results from the F-statistics of the Wald test. Implying the null hypothesis of the test will be:

$\mu_{1}=\mu_{2}=0$ (no long-run relationship).

Against the alternative hypothesis.

$\mu_{1} \neq \mu_{2} \neq 0$ (a long-run relationship exists thus co-integration).

The F-statistics of this test is then compared with that of the Narayan critical values at $5 \%$ level of significance with unrestricted and no trend series. The long run variables are regressed and the error term inserted as an explanatory variable, this gives the error correction model (ECM)as seen below:

$$
\begin{aligned}
& \Delta \text { economic growth } \text { g }_{t}=\gamma+\sum_{i=1}^{p} \phi_{i} \Delta \text { economic growth }{ }_{t-i} \\
& +\sum_{i=0}^{q} \beta_{i} \Delta \text { financialdevelopment }_{t-i} \\
& +\sum_{i=0}^{p} \partial_{i} \text { sother factors } \text { f }_{t-i} \alpha \mathrm{ect}_{\mathrm{t}-1}
\end{aligned}
$$

Where ect is the Error correction term.

The Wald test used is meant to verify if there exist short-run causality from financial development to economic growth.

The two sets of critical values reported in Pesaran et al. (2001) provides critical value bounds for all classifications of the regressors into purely $\mathrm{I}(1)$, purely $\mathrm{I}(0)$ or mutually co-integrated. If the calculated F-statistics lies above the upper level of the band, the null hypothesis is rejected indicating the presence of co-integration. On the other hand, if the calculated $F$-statistics is below the upper critical value, we cannot reject the null hypothesis of no co-integration. However, if the critical value lies between the bounds, a conclusive inference cannot be made without knowing the order of integration of the underlying regressors. Recently, Narayan (2005) argues that existing critical values which are based on large sample sizes cannot be used for small sample sizes. Hence, Narayan (2005) regenerated the set of critical values for the limited data ranging from 30 to 80 observations by using the Pesaran et al. (2001)'s GAUSS code. With a limited 
annual time series data on Cameroon financial development and economic growth, this study employs the critical values of Narayan (2005) for the bounds F-test rather than Pesaran et al. (2001).

\section{Tests of goodness of fit}

\section{Serial correlation}

To verify the presence of serial correlation in the model, the Breusch-Godfrey Serial Correlation LM Test is applied. If the probability of R-squared is significant, the null hypothesis is accepted and concluded that the model has no serial correlation, but if it is insignificant, the null hypothesis is rejected and concluded that the model is serially correlated.

\section{Stability test (CUSUM test)}

In addition, due to the structural changes in the Cameroon economy, it is likely that macroeconomic series may be subjected to one or multiple structural breaks. As a result of this, the stability of the short-run and long-run coefficients is checked through the cumulative sum (CUSUM) and cumulative sum of squares (CUSUMSQ) tests proposed by Brown et al. (1975). Unlike the Chow test which requires break point(s) to be specified, the CUSUM and CUSUMSQ tests are quite general tests for structural change in that they do not require a prior determination of where the structural break takes place. That is, the robustness of the model is verified using the tests for serial correlation, CUSUM and CUSUM squares test for the stability of the model.

\section{Results}

Preliminary results 1.1 unit root test for Cameroon

The results of preliminary test will be presented in this section and it permits us to know the structure of the time series data. The results of the Unit root test, granger causality, lag length determination will as well be presented. Table 3 below shows the results of the unit root test.

The results above shows all the variables are integrated in the same order. This implies, all these variables will become stationary after first difference thus, they are integrated of order one. The conformity of these results is equally tested using the PhillipsPerron unit roots test, it shows that all variables are integrated of order one. This is in conformity with the results obtained from the Augmented Dickey Fuller test. This means that a linear combination of the variables will give a stationary series, thus a great possibility of co-integration. It is therefore imperative to test for the presence of co-integration, the bound test will be used, before that the number of optimal lags will be determined, this is done using the akaike and Swartz citeria, Table 4 below shows the results of this test.

\section{Choice of lag length}

It is very important to know the optimal lag length, especially in order to estimate the direction of causality. The Akaike and Schwarz criterion is used in this study. Table 4 below shows the results of these tests.

The Akaike information and Schwarz criteria used for determination of optimal lag length requires that, the lag length with the smallest critical value for both criterions be chosen. We see from above that lag 1 have the smallest Akaike and Schwarz 
Table 3 Unit root test

\begin{tabular}{|c|c|c|c|c|c|}
\hline \multirow[t]{3}{*}{ Variables } & \multicolumn{4}{|l|}{ Trend \& inter } & \multirow[t]{3}{*}{ Decision } \\
\hline & \multicolumn{2}{|l|}{ Level } & \multicolumn{2}{|c|}{ First difference } & \\
\hline & $\begin{array}{l}\text { Augmented } \\
\text { Dickey Fuller }\end{array}$ & Phillips- Perron & $\begin{array}{l}\text { Augmented } \\
\text { Dickey Fuller }\end{array}$ & Phillips- Perron & \\
\hline GDP growth (annual \%) & -3.370565 & -3.370565 & $-3.605024^{b}$ & $-3.605024^{b}$ & $\mathrm{I}(1)$ \\
\hline $\begin{array}{l}\text { Domestic credit to private sector } \\
\text { (\% of GDP) }\end{array}$ & -0.829053 & -0.880052 & $-5.007785^{a}$ & $-5.161468^{\mathrm{a}}$ & $\mid(1)$ \\
\hline Bank deposits as \% of GDP & -1.532913 & -1.619798 & $-4.227425^{a}$ & $-4.2245425^{b}$ & $\mathrm{I}(1)$ \\
\hline $\begin{array}{l}\text { Money and quasi money (M2) as } \\
\% \text { of GDP }\end{array}$ & -1.501459 & -1.564212 & $-4.555150^{\mathrm{a}}$ & $-4.555150^{\mathrm{a}}$ & $\mid(1)$ \\
\hline Government expenditure(\%GDP) & -2.753952 & -2.093615 & $-4.803761^{\mathrm{a}}$ & $-4.742368^{\mathrm{a}}$ & $\mathrm{I}(1)$ \\
\hline Private investment & -2.245010 & -2.245010 & $-4.459368^{\mathrm{a}}$ & $-4.459368^{b}$ & $\mathrm{I}(1)$ \\
\hline
\end{tabular}

$\mathrm{a} / \mathrm{b} / \mathrm{c}$ indicates stationarity at $1 \% / 5 \% / 10 \%$ respectively

Source: Author

information criteria. With information on the lag length, it is now possible to verify if the variables are co-integrated using the bound test technique.

\section{Bound testing for co-integration analysis}

The results of the co-integration test are presented below in Table 5, unrestricted intercept and unrestricted trend is used. It is clear from the table that there is a long run relationship amongst the variables. The computed F-statistics (8.4) is higher than the critical values of $3.79,4.25$ and 5.23 at $10 \%, 5 \%$ and $1 \%$ respectively from the Narayan (2005) table. This means that the null hypothesis of no co-integration between financial development indicators and economic growth is rejected.

The table above indicates estimates of the finance-growth nexus, the effect of credit to private sector, money supply and deposits on economic growth was assessed. The results show that the 1 period lag has a positive and significant impact in the long run. The long run analysis reveals that, a $1 \%$ increase in credit to private sector leads to an increase in economic growth by $0.38 \%$ while $1 \%$ increase in money supply triggers an increase in GDP by $1.9 \%$. The results equally indicate that increasing deposits by $1 \%$ leads to an increase in GDP by $1.24 \%$. This therefore means there is a long run relationship between financial development and economic growth.

This finding confirms that of Mandiefe (2015) who analyzed the impact of financial development on economics growth for Cameroon and South Africa. Table 6 below shows the coefficients of the long run impact of financial development on economic growth in Cameroon.

The table above confirms the bound test results with a positive and significant long run relationship between the financial development indicators and economic growth. This positive and significant impact is coherent with the findings by Khan et al. (2005) and Khan and Qayyum (2006).

Table 4 Akaike and Schwarz lag length test

\begin{tabular}{lll}
\hline Lag length & Akaike information criteria & Schwarz criterion \\
\hline 3 & 4.639583 & 5.749767 \\
2 & 4.650764 & 5.475241 \\
1 & 4.614442 & 5.198627 \\
\hline
\end{tabular}

Source: Author using Eviews 8 
Table 5 Bound testing for co-integration analysis

\begin{tabular}{lllllll}
\hline Computed & \multicolumn{7}{l}{ Critical bounds } \\
\cline { 2 - 7 } F-statistic & $10 \%$ & & $5 \%$ & & $1 \%$ & \\
\hline 8.48 & $I(0)$ & $I(1)$ & $I(0)$ & $\mid(1)$ & $\mid(0)$ & $\mid(1)$ \\
& 2.55 & 3.33 & 3.12 & 3.93 & 4.25 & 5.20 \\
\hline
\end{tabular}

Source: Author

Error correction model (Table 7)

The regression table above shows that there is a negative but not significant relationship between credit to private sector and economic growth in the short run, however in the long-run, this effect is positive and statistically significant. This therefore means that the efficient allocation of credit to profitable projects has the potential of improving economic activities and subsequently economic growth.

The supply of money (M2) has a positive and significant impact on economic growth in the short-run, thus using the banking sector to increase the supply of money would facilitate the financing of the economy. The regression results show a negative but significant impact on economic growth in the short-run. This is principally due to the over-liquid nature of the financing system where deposits are dominated with short term deposits (Piabuo et al. 2015). However, in the long-run, deposits can be used as a vital resource for long term investments which have significant effects on output and economic growth.

The error correction mechanism (ECM) is used to verify the short-run relationship between credit to private sector, deposits, monetary mass (M2) and economic growth (GDP). The rule for the existence of a short-run relationship between financial development and economic growth is that the coefficient of the error correction term should be negative and it should be significant. Our results above confirms this, thus we can conclude that the there is a return to equilibrium in case of disequilibrium at a rate of adjustment of $80.5 \%$. This implies $80.5 \%$ of errors of previous year are corrected within the current year. The divergence of results in the short-run and long-run equilibrium explains the fragility of the financial system of Cameroon. The system cannot quickly adjust to shocks in the short-run, this is principally due to the dominance of the banking sector which is over liquid and information efficiency is very low in the system. The financial system is made up of the Douala stock exchange which is still at its embryonic stage (Piabuo et al. 2015) with very low capitalization and few listed firms, thus limiting short-run adjustments. The underdeveloped nature of the financial system is equally characterized by high information asymmetry which limits the effective financing of the private sector by banks thus reducing short run benefits to the economy.

Table 6 ARDL coefficients for long-run

\begin{tabular}{llll}
\hline Variable & Coefficient & Std. Error & t-Statistic \\
\hline Credit to private sector(\% GDP) & $0.387269^{\mathrm{b}}$ & 0.139261 & 2.780880 \\
Deposits (\% GDP) & $1.246879^{\mathrm{b}}$ & 0.507556 & 2.456631 \\
M2 (\% GDP) & $1.977286^{\mathrm{a}}$ & 0.582636 & 3.393687 \\
Government expenditure & 0.159012 & 0.225122 & 0.706338 \\
Private investment & 0.744684 & 0.456850 & 1.630042 \\
\hline
\end{tabular}

Note: ${ }^{a}{ }^{b}$ and ${ }^{c}$ imply significant at the 1,5 and $10 \%$ levels respectively Source: author analysis 
Table 7 Short- run impact of financial development on economic growth

\begin{tabular}{|c|c|c|c|}
\hline Variable & Coefficient & Std. Error & t-Statistic \\
\hline$\overline{\Delta \mathrm{GDP}}$ & $-0.253700^{c}$ & 0.125958 & -2.014158 \\
\hline$\Delta$ Credit to private sector(\% GDP) & -0.016350 & 0.160491 & -0.101872 \\
\hline$\Delta$ Deposits (\% GDP) & $-1.536301^{\mathrm{a}}$ & 0.528120 & -2.909000 \\
\hline$\Delta \mathrm{M} 2(\% \mathrm{GDP})$ & $1.458098^{\mathrm{a}}$ & 0.406698 & 3.585214 \\
\hline$\Delta$ Government expenditure & $0.644298^{\mathrm{a}}$ & 0.285455 & 2.257095 \\
\hline$\Delta$ Private investment & $-2.476650^{b}$ & 0.607828 & -4.074589 \\
\hline $\mathrm{ECM}(-1)$ & $-0.805787^{a}$ & 0.184469 & -4.368139 \\
\hline R-squared & 0.685374 & & \\
\hline Adjusted R-squared & 0.612768 & & \\
\hline S.E. of regression & 2.213418 & & \\
\hline Sum squared resid & 127.3797 & & \\
\hline Log likelihood & -69.11095 & & \\
\hline
\end{tabular}

Test for existence of serial correlation Here the Breusch-Godfrey Serial Correlation LM Test is used; the table below shows the results of this test (Table 8).

The table above shows that there is no serial correlation and that our model is good. To further verify this, the stability test is used to see if our model is stable in the long-run.

Result of stability tests To assess the stability of the long-run and short-run relationship between financial development and economic growth, the CUSUM and CUSUM-squared tests are applied at 5\% level of significance. When the CUSUM line lies in-between the lines of the level of significance, it shows the model is stable. However, variables are unstable when the CUSUM line is out of these two lines.

CUSUM stability test (Fig. 1) We see from the graph above that the blue line lays within the $5 \%$ level of significance, thus there is a long- run stability between the variables in our model.

CUSUM square stability test This test is used to verify the stability of the model over time. This can be seen on the graph presented below (Fig. 2).

From the graph above, it can be seen that the CUSUM of Squares line lays inbetween the lines of the level of significance. This implies the model is stable and thus can be used for causality, bound test and long-run association. The different tests carried out above have proven our model is suitable to estimate the causal link as well as the long and short-run relationship between financial development and economic growth.

Table 8 Serial correlation test

\begin{tabular}{llll}
\hline \multicolumn{2}{l}{ Breusch-Godfrey serial correlation LM test: } & & \\
\hline F-statistic & 0.559023 & Prob. F $(2,13)$ & 0.5849 \\
Obs*R-squared & 2.534166 & Prob. Chi-Square(2) & 0.2817 \\
\hline
\end{tabular}




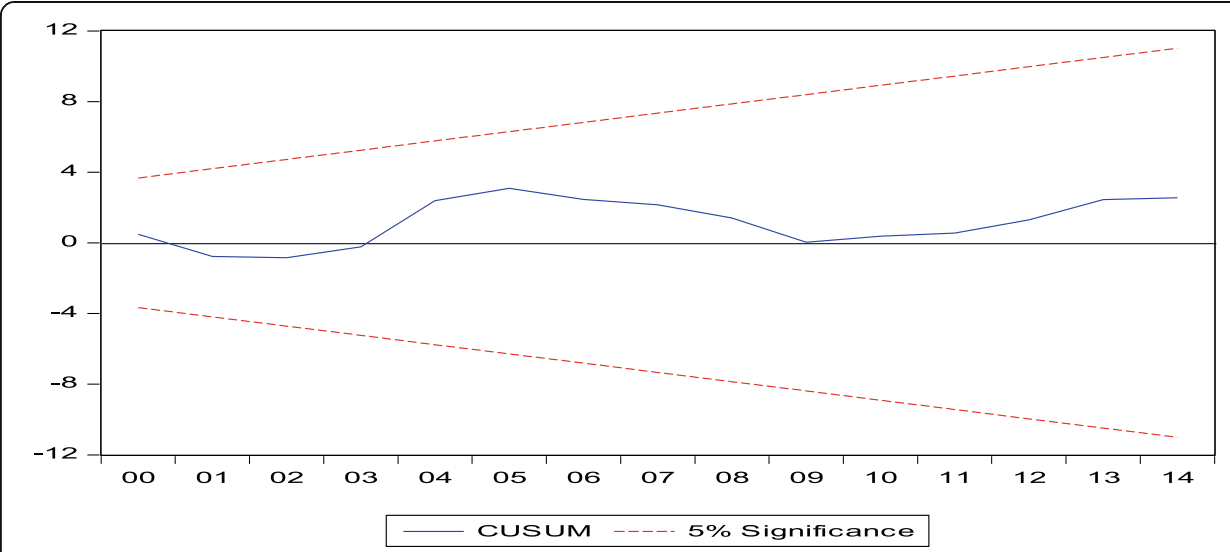

Fig. 1 CUSUM stability test

\section{Discussion of results, policy implication and conclusion \\ Discussion of results}

The findings in this paper have broadly confirmed the conventional view which sustains that financial development has a positive and significant impact on economic growth. Although the view may not be universal, it is widely believed that financial system development boosts economic activities in an economy which leads to economic growth. These results confirm those of Tabi et al. (2011) who used a time series data of 35 years to show that financial development had a positive and significant long-run effect on economic growth in Cameroon. These results as well collaborates with the findings of a study carried out by Beck et al. (2000) on the impact of financial development on economic growth in which it was discovered that there exist a positive link between the exogenous component of financial development and economic growth.

Evidence of long-run co-integration between financial development and economic growth in this study collaborates with the verifications made by Luintel and Kaln

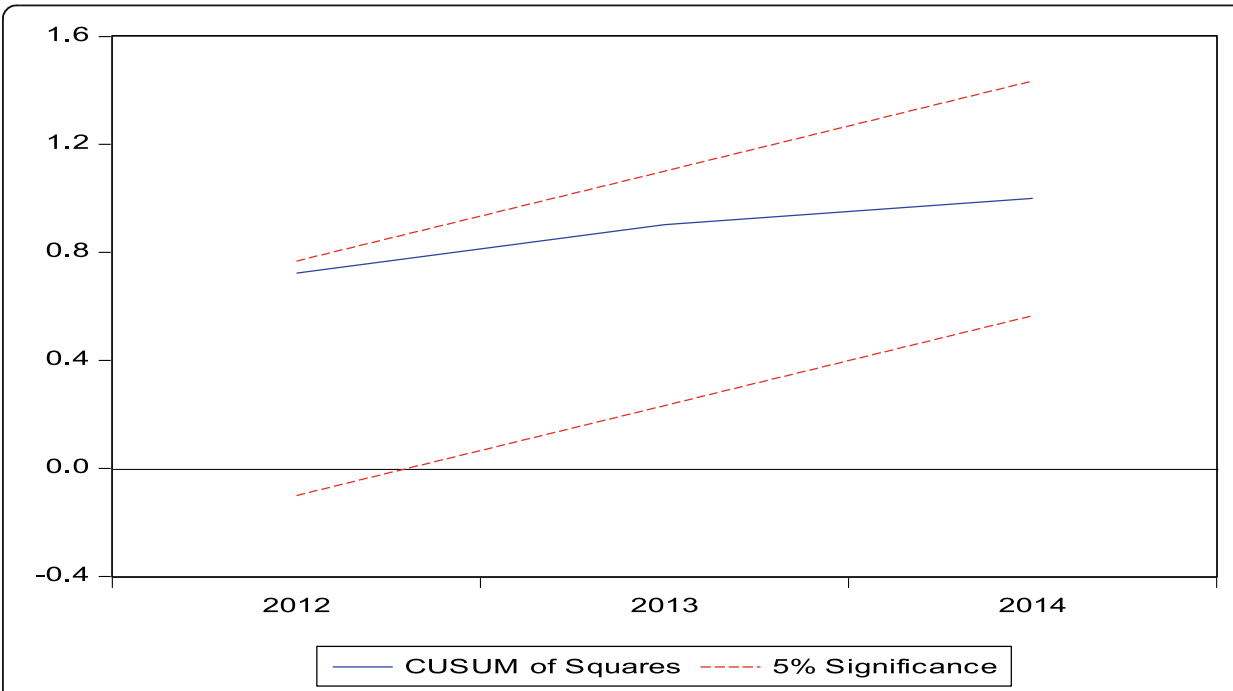

Fig. 2 CUSUM square stability test 
(1999) using the Multivariate Vector Auto Regressive model and found a doublecausality link between financial development and economic growth in sample of 90 countries. However, these results contradict with the findings of Aghion et al. (2004) who found an insignificant direct impact of financial development on economic growth and further concluded that the level of credits as a percentage of GDP influences growth only in the intermediary stages of development.

The long- run relationship between financial development and economic growth in this study is in collaboration with the works of Mandiefe (2015) which shows that improvement in the financial sector consistently mitigates investment and therefore boosts growth in an economy. Hence, the structural reforms such as financial liberalization which was engineered by the IMF in the 1980s and has been adopted by policy makers in Cameroon play most of the part to financial sector development. The objective of these reforms has been to reduce trade barriers and increase foreign investment in the country (Asongu 2014). However, it is interesting to note that effective economic freedom has consistently been found to improve on financial allocation efficiency (Asongu 2013d) which diminishes issues of surplus liquidity. This eventually recourse both formal and informal financial services and therefore leads to investment in both formal and informal sectors (Piabuo et al. 2015). In addition, with advancement in ICTs, the Cameroonian banking industry is increasingly becoming synchronized that is, the rate at which banks adjust when is shocks is growing leading to a fall is bank crisis.

The mechanism that translates financial development to economic growth is divergent in Africa. This is principally because the level of financial development and liberalization is not uniform among countries. The results of this study indicates that there is a long-run relationship between financial development and economic growth, in the short-run, credit to private sector and investment have a positive impact on economic growth. Mandiefe (2015) highlights thatcountries with well-developed financial system turn to converge towards their long-run equilibrium faster than countries with less developed financial system.

\section{Policy implication}

This study outlines the importance of suitable financial policies in Cameroon and goes further to extend literature on the positive impact of financial development on economic growth. From the empirical results which was based on financial system development, it has been proven consistently that financial development is a fundamental determinant of economic growth of many nations with Cameroon inclusive and an increase in the activities of this sector further mitigates growth. The principal policy recommendation therefore is that adequate consideration and proper recognition such as provision of suitable financial reforms should be given to the financial sector in Cameroon as a determinant of economic growth.

\section{Conclusion}

This paper highlights the positive and significant impact of financial development on economic growth which was earlier analyzed by authors such as Bangehot (1873) and Schumpeter (1911).The unit root, co-integration and the granger causality tests were 
conducted to reveal these interesting results. The results from this study show that all variables included in the model were integrated in the same order. It equally shows that there exist co-integration between financial development and economic growth; there is a long-run relationship between the variables in the study. In addition, unilateral relationships were discovered to run between variables in this study. This therefore implies that by increasing the amount of money supply in the economy, improving the functions of financial institutions and intermediaries, and improving the investment environment of Cameroon will boost economic growth, which will eventually lead to economic development.

\section{Acknowledgements}

We Thank Dr. Chupezi Julius for his advice and encouragement while we were working on this paper.

\section{Funding}

Funding for this paper is entirely by the authors. Sir, I will be very happy to have my article published in your prestigious Journal. Accept expressions of my greatest satisfaction and joy.

\section{Authors' contributions}

This work was carried out in collaboration between all authors. Author PJT designed the study developed the theoretical and empirical literature review equally contributed in the discussion of results. Author SMP performed the statistical data analysis and discussion of results. Both authors read and approved the final manuscript.

\section{Competing interests}

The authors declare that they have no competing interests.

\section{Publisher's Note}

Springer Nature remains neutral with regard to jurisdictional claims in published maps and institutional affiliations.

Received: 5 January 2017 Accepted: 20 October 2017

Published online: 07 November 2017

\section{References}

Adu G, Marbuah G, Mensah JT (2013) Financial development and economic growth in Ghana: does the measure of financial development matter? Review of Development Finance 3(4):192-203

Adusei M (2013) Financial development and economic growth: evidence from Ghana. International Journal of Business and Finance Research 7(5):61-76

Aghion, P., Howitt, P., and Mayer-Foulkes, D. (2004), "The effect of financial development on convergence: theory and evidence", NBER working paper 10358

Ahmed AD (2006) The impact of financial liberalization policies: the case of Botswana. Journal of African Development 1(1):13-38

Al-Malkawi HAN, Marashdeh HA, Abdullah N (2012) Financial development and economic growth in the UAE: empirical assessment using ARDL approach to co-integration. International Journal of Economics and Finance 4(5):105-115. https://doi.org/10.5539/ijef.v4n5p105

Andersen TB, Tarp F (2003) Financial liberalization,financial development and economic growth in LDCs. J Int Dev 15(2): 189-209

Asongu, S. A. (2011a): "New financial intermediary development indicators for developing countries". MPRA Paper No. 30921

Asongu, S. A. (2011b): "Law, finance, economic growth and welfare: why does legal origin matter?. MPRA Paper No. 33868

Asongu, S. A. (2011c): "Financial determinants of human development in developing countries". MPRA Paper No. 33949

Asongu, S. A. (2011d): "Law, finance and investment: does legal origin matter?". MPRA Paper No. 34698

Asongu SA (2012) Financial sector competition and knowledge economy: Evidence from SSA and MENA countries. J Knowl Econ

Asongu SA (2013) How has politico-economic liberalization affected financial allocation efficiency? Fresh African evidence. Econ Bull 33(1):663-676

Asongu SA (2014) Liberalization and financial sector competition: a critical contribution to the empirics with an African assessment. South African Journal of Economics

Bagehot W (1873) Lombard street: a description of the money market. John Murray, London

Beck T, Levine R (2004) Stock markets, Bank and growth: panel evidence. J Bank Financ 28:423-442

Beck T, Levine R, Loayza N (2000) Finance and the sources of growth. J Financ Econ 58:261-300

Bernard AU, Austin A (2011) The role of stock market development on economic growth in Nigeria:a time-series analysis. African Research Review 5(6):213-230

Bloch H, Tang SHK (2003) The role of financial development in economic growth. Prog Dev Stud 3(3):243-251. doi: 10.1191/1464993403ps063pr

Boulika G, Trabelisi M (2002) Financial development and long-run growth: granger causality in bivariate VAR structure. Evidence from Tunisia:1962-1997 
Buffie E (1984) Financial repression, the new structuralists, and stabilization policy in semi-industrialized economies. J Dev Econ 14:305-322

Christopoulos D, Tsionas E (2004) Financial development and economic growth: evidence from panel unit root and cointegration tests. J Dev Econ 73(1):55-74

De Gregorio J, Guidotti PE (1995) Financial development and economic growth. World Dev 23(3):433-448

Djoumessi, E. C. (2009)' "Financial development and economic growth: a Comperative study between Cameroon and South Africa", Submitted in fulfillment of the requirements for the degree of master of commerce

Elie N (2015) Financial development and economic growth in sub-Saharan Africa: a dynamic panel data analysis. European Journal of Sustainable Development 4(2):369-378

Fry MJ (1978) Money or capital or financial deepening in economic development. J Money, Credit, Bank 10(4):464-475

Fry MJ (1980) Savings, investment, growth and the cost of financial repression. World Dev 8(4):317-327

Fry MJ (1988) Money, interest and banking in economic development. Johns Hopkins University Press, Baltimore

Galbis V (1977) Financial intermediation and economic growth in less-developed countries: a theoretical approach. J Dev Stud 13(2):58-72

Goldsmith RW (1969) Financial structure and development. Yale University Press, New Haven

Gurley JG, Shaw ES (1955) Financial aspects of economic development. Am Econ Rev 45(4):515-538

Güryay E, Şafakli OV, Tüzel B (2007) Financial development and economic growth: evidence from northern Cyprus. International Research Journal of Finance and Economics, ISSN 1450-2887(8):57-62

Hakeem, M., \& Oluitan, O. (2013). Financial development and economic growth in SSA: a panel econometric approach. Res Appl Econ, 5(2), 42-69. doi: 10.5296/rae.v5i2.1492

Hicks J (1969) A theory of economic history. Claredon Press, Oxford

Huran P, Chun W (2013) Financial development and economic growth: a new investigation. J Econ Dev 38(1)

Ikhide SI (1993) Positive interest rates: financial deepening and the mobilization of savings in Africa. Development Policy Review 11(4):367-382

Islam MR, Habib MW, Khan MH (2004) Time series analysis of finance and growth. The Bangladesh Development Studies 30(1/2):111-128

Jeanneney SG, Hua P, Liang Z (2006) Financial development, economic efficiency, and productivity growth: evidence from China. Dev Econ 44:27-52. doi: 10.1111/j.1746-1049.2006.00002.x

Jung WS (1986) Financial development and economic growth: international evidence. Econ Dev Cult Chang 34:333-346

Kar, M. and E. J. Pentecost. 2000. "Financial development and economic growth in Turkey: further evidence on the causality issue,"Loughborough University economic research paper no. 00/27

King RG, Levine R (1993) Finance and growth: Schumpeter might be right. Q J Econ 108(3):717-737

Levine R (1997) Financial development and economic growth: views and agenda. J Econ Lit 35:688-726

Levine, R. (2004), "Finance growth, theory, evidence, and mechanism", In Handbook of Economic Review, Vol. 88, n0 3, PP. 537-558

Levine R, Zervos S (1996) Stock market development and long run growth. World Bank Econ Rev 10(2):323-340

Lucas R (1988) On the mechanics of economic development. J Monet Econ:3-42

Luintel KB, Khan M (1999) A quantitative reassessment of the finance-growth nexus: evidence from a multivariate VAR. J Dev Econ 60(2):381-405

Mandiefe, PS,(2015) The impact of financial sector development on economic growth: analysis of the financial development gap between Cameroon and South Africa (May 2015). Available at SSRN: https://ssrn.com/abstract= 2616296 or doi:10.2139/ssrn.2616296

Narayan P (2005) The saving and investment nexus for China: evidence from co-integration tests. Appl Econ 37(17):1979-1990

Ndikumana, L. (2001),Financial markets and economic development in Africa, political economy research institute, University of Massachusetts Amherst, working paper series, number 17

Padilla, S.B., Mayer, H.P. (2002), Is Financial Development Important for Economic Growth in Slovenia. http://www.epoc uni-bremen.de/publications/pup2003/files/Budapest_Padilla.PDF

Pesaran MH (1997) The role of economic theory in modelling the long-run. Econ J 107:178-191

Pesaran MH, Shin Y (1995) Estimating long-run relationships from dynamic heterogeneous panels. J Econ 68:79-113

Pesaran MH, Shin Y (1998) Generalized impulse response analysis in linear multivariate models. Econ Lett 58:17-29

Pesaran MH, Shin Y, Smith RJ (2001) Bounds testing approaches to the analysis of level relationships. J Appl Econ 16:289-326

Piabuo SM, Baye FM, Tieguhong JC (2015) Effects of credit constraints on the productivity of small and medium-sized enterprises in Cameroon. Journal of Economics and International Finance 7(9):204-2012. doi: 10.5897/JEIF2015.0688

Ram R (1999) Financial development and economic growth: additional evidence. J Dev Stud 35(4):164-174

Robinson J (1952) The generalization of the general theory. In: The rate of interest and other essays. MacMillan, London

Schumpeter JA (1911) The theory of economic development, an inquiry into profits, capital, credit, interest, and the business cycle, translation 1934. Harvard University Press, Cambridge Second Printing 1936; third printing 1949

Schumpeter JA (1912) Theorie der Wirtschaftlichen Entwicklung (the theory of economic development). In: Leipzig: dunker and Humblot, translated by Redvers Opie. Havard University Press, Cambridge, MA

Seck D, EINil Y (1993) Financial liberalization in Africa. World Dev 21:1867-1881

Shaw ES (1973) Financial deepening in economic development. Oxford University Press, New York

Stern N (1989) The economics of development: a survey. Econ J 99(397):597-685

Tabi A, Njong A, Neba C (2011) Financial development and economic growth in Cameroon. Journal of Economics and International Finance Vol 3(6):367-375

Ujunwa A, Salami OP (2010) Stock market development and economic growth: evidence from Nigeria. European Journal of Economics, Finance and Administrative Sciences 25:44-53

Van Wijnberg S (1983) Interest rate management in LDCs. J Monet Econ 12(3):433-452

Yıldırım S, Özdemir BK, Doğan B (2013) Financial development and economic growth nexus in emerging European economies: new evidence from asymmetric causality. International Journal of Economics and Financial Issues 3(3):710-722 